\title{
КОНСТИТУЦІЙНІ ПРИНЦИПИ ПРАВОВӦ̈ ПОЛІТИКИ У СФЕРІ НЕДИСКРИМІНАЦІї ЗА ВІКОВОЮ ОЗНАКОЮ
}

\author{
ГРЕНЬ Наталія Михайлівна - кандидат юридичних наук, суддя ЛЬвівського \\ окружного адміністративного суду
}

https://orcid.org/0000-0001-5780-9423

УДК 304.4

DOI 10.32782/NP.2021.1.7

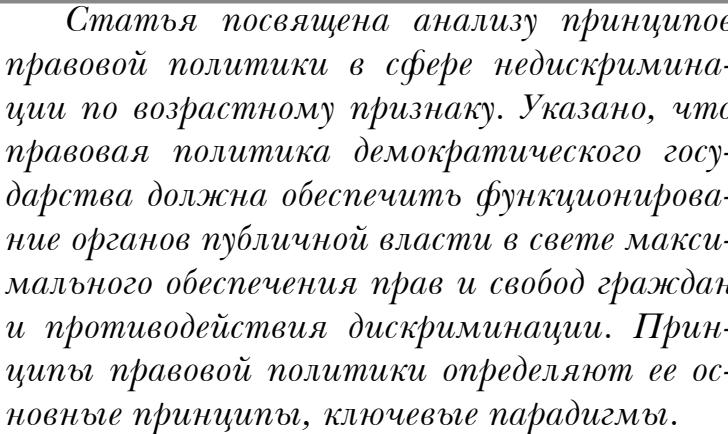

Автором определенъ основнвие приниипъ правовой политики в исследуемой сфере. Первичнълм и основополагаюшим выступает приниип верховенства права. Этот приници стал основой Функиионирования конституицонализма. Верховенство права указъвает на необходимость существования системь правовъхх требований, которвие заключаются в бормировании, изменении, прекращении бункиионирования правовъхх норм, осуществлении правотворческой деятельности и правореализацийнои практики, существование комплекса нормативно-правовъх актов. Однако только указаннъим нельзя в полной мере удовлетворить общественнъие интересъи. В содержание приниипа законности вътекает необходимость функиионирования органов государственной власти и местного самоуправления с неуклоннъим соблюдением определенных правовъгх норм, в соответствии с законом и в порядке предусмотреннъим законом.

По мнению автора, принцип равенства также следует определить как общий приници недискриминации. Конституционное закрепление равенства по признаку возраста все же не может быть оценено положительно. Учитьлвая актуальность вопроса, его широту следовало все же возраст, как признак не относить к «другим признакам», а добавить в первичнъий перечень. Указанное крайней мере способствовало бъ актуализации проблематики на научном и праксиологического уровнях.

Также исследовано приници справедливости, позиционируется как справедливое распределение государственнъх и общественнъх ресурсов и механизмов, что является весомъим бактором как предотвращение так и преодоления дискриминации по возрасту.

Ключевъие слова: принципъл, правовая политика, дискриминация, возраст, признаки дискриминации.

\section{Постановка проблеми}

Правова політика держави, що задекларувала себе як правова та демократична повинна грунтуватися на цінності прав та свобод людини і громадянина. Дискримінація за будь якою ознакою - це первинне порушення принципу рівності людини. Нажаль, у сучасному суспільстві, незважаючи на значні зусилля міжнародних інституцій та наявність спеціальних законодавчих норм, подолати проблему дискримінації або дещо нормалізувати наявні негативні прояви не вдається. Цей фактор обумовлений багатьма чинниками, серед яких соціально-економічна криза, загрози пандемічного характеру, глобалізаційні виклики, неефективність 
реформ чинного законодавства та юридичної практики, відсутність дієвих гарантій у сфері прав та свобод громадян. Вагомим чинником також виступає стан правової культури та толерантності громадянського суспільства.

За результатами соціологічного опитування, проведеного Фондом демократичних ініціатив імені Ілька Кучеріва, серед усіх цінностей толерантність займає останнє місце, і ця категорія $є$ вагомою тільки для $31 \%$ респондентів, проте все ж порівняно з 2016 роком цей показник зріс на $6 \%$ [1]. Тому вагомо на науковому рівні присвячувати більшу увагу питанням подолання дискримінації людей та вироблення національних стандартів подолання цього ганебного явища.

\section{Стан дослідження}

Питаннями дискримінації в сучасному національному праві займалося багато науковців. Значними доробками відзначилися представники як загальнотеоретичної юриспруденції, так і конституційного права, зокрема Д. Бєлов, Ю. Бисага, Н. Дрьоміна-Волок, I. Жаровська, Г. Журавльова, М. Скорик, П. Рабінович, В. Селіванов та інші. Однак актуальність проблематики вказує на потребу окремого аналізу питання подолання дискримінації за ознакою віку, а також аналізу правової політики в цьому напрямку.

Метою цієї статті є проведення аналізу принципів правової політики у сфері недискримінації за віковою ознакою.

\section{Виклад основних положень}

Дискримінація за віком займає лідируючі позиції серед інших ознак дискримінації. Вказане зумовлено тим, що будь-яка особа може піддаватися дискримінації за цією ознакою, починаючи від дитячого віку до осіб літнього віку особливо. Останні підпадають під дискримінаційні чинники у зв'язку зі зростанням тривалості життя та низьким рівнем, народжуваності. За офіційними даними народжуваність в Україні знизилася на $40 \%$ за 10 років У 2020 році в Україні зафіксовано найнижчу народжуваність за останні 10 років. Вона склала 293457 осіб, тоді коли смертність сягнула 616835 осіб [2]. Тому вагомим питанням загальнодержавного значення є оновлення правової політики у сфері недискримінації за ознакою віку.

Правову політику як актуальну категорію у світлі репрезентованої тематики розуміємо як певну форму «безпосереднього правового вираження державної політики у будь-якій загальнозначущій сфері суспільного життя, яке упорядковується та управляється органами державної влади і органами місцевого самоврядування» (за визначенням В. Селіванова) [3, с. 9]

Вагомо виокремити основні, загальні принципи недискримінації та відобразити їх у контексті недискримінації за віковою ознакою. Вони відображають ті основні базисні компоненти, які відображають основну сутність, тобто максимальну оборону прав та свобод громадян.

У пошуку цих принципів звернемося до наукової позиції I. Жаровської, котра правильно зауважує, що «правова політика цивілізованих народів повинна відповідати аксіологічним принципам верховенства права, демократизму, гуманізму, законності, узгодженості інтересів окремого індивіда, суспільства та держави тощо» [4, с.49].

Загалом визначимо основні принципи правової політики у досліджуваній сфері.

Первинним i основоположним виступає принцип верховенства права. Стаття 8 Конституції вказує, що «в Україні визнається і діє принцип верховенства права» [5]. «Принцип верховенства права є визначальним при формуванні всіх інститутів держави і суспільства в цілому, оскільки закріплює за правами людини значення найвищої соціальної цінності, головного суспільного орієнтиру. Тому варто погодитись із думкою, що принцип верховенства права виступає «принципом принципів» [6, с.65].

Цей принцип став основою функціонування конституціоналізму, який розуміють як правове явище у вузькому та широкому тлумаченні. У вузькому конституціоналізм позиціонують через верховенство норм Основного закону у всій системі права та його визначальне становище серед джерел права. Проте такого розуміння виявилося 


\section{Теорія, історія держави і права, конституційне право}

недостатньо. Тому розширюють його шляхом позиціонування конституціоналізму як форми державний конституційний устрій держави, що визначає верховенство права у всіх сферах людського та державно-громадського співіснування.

Варто погодитися з $\mathcal{\lambda}$. Шевченко в тому, що «цей принцип передбачає побудову державного ладу на грунті обов'язкового дотримання органами державної влади, судочинства, місцевого самоврядування, їхніми посадовими особами, законотворцями справедливих, обгрунтованих рішень у будьякій ситуації, незважаючи на силу зовнішніх впливів, які провокують здійснення протилежного» $[7$, с.8].

Принцип законності - це ще один вагомий принцип правової політики у сфері подолання дискримінації за ознакою віку.

Звернувшись до наукових доробківВ. Савенка, відзначимо, що автор слушно розуміє ії як «сукупність вимог, гарантій, що забезпечують порядок у державі. Зміст законності полягає в необхідності суворого, абсолютного та конкретного дотримання всіма без винятку суб'єктами права усіх приписів закону та інших нормативно-правових актів. Принцип законності виявляється у двох взаємопов'язаних вимогах: 1) діяти відповідно до положень нормативно-правових актів; 2) виявляти ініціативу з метою забезпечення панування права [8, с.16]

Конституція України предметно не виокремлює принцип конституційної законності, хоча його можна вивести 3 уже цитованої ст. 8 в контексті верховенства права, оскільки ці дві категорії є взаємопов'язані та нероздільні. Верховенство права вказує на необхідність існування системи правових вимог, що полягають у формуванні, зміні, припиненні функціонуванні правових норм, здійсненні правотворчої діяльності та правореалізаційної практики, існуванні комплексу нормативно правових актів. Проте тільки вказаним не можна повною мірою задовільнити суспільні інтереси.У зміст принципу законності також відносимо і функціонування органів державної влади та місцевого самоврядування з неухильним дотриманням визначених правових норм, відповідно до закону та в порядку, передбаченому законом. Тому до конституційного закріплення вказаного принципу можемо віднести і статтю 6 Конституції України, де передбачено, що органи законодавчої, виконавчої і судової влади у встановлених межах і відповідно до законів.

На нашу думку, принцип рівності також слід визначити як загальний принцип недискримінації. Науковці практично погодилися $з$ поглядом на принцип рівності як на сутність взамовідносин між людьми та відносин між людьми і державою. «Рівність полягає скоріше в тім, що 3 тієї загальної властивості людей, що вони є людьми, з рівності людей як людей вона виводить право на рівне політичне й відповідно соціальне значення всіх людей або, принаймні, всіх громадян цієї держави або всіх членів цього суспільства» [9, с.68]

Конституція України присвятила цьому принципу навіть не одну, а практично групу статей. Першочергово це стаття 21, де вказано, що "усі люди $є$ вільні і рівні у своїй гідності та правах». Продовжуючи цю позицію, стаття 23 вказує, що «кожна людина має право на вільний розвиток своєї особистості, якщо при цьому не порушуються права і свободи інших людей», і в подальшому стаття 24 вже предметно визначає, що громадяни мають рівні конституційні права і свободи та є рівними перед законом. Зміст статті вказує про недискримінацію за різними ознаками: "Не може бути привілеїв чи обмежень за ознаками раси, кольору шкіри, політичних, релігійних та інших переконань, статі, етнічного та соціального походження, майнового стану, місця проживання, за мовними або іншими ознаками» [5].

Останне 3 погляду рівності за ознакою віку все ж не може бути оцінено позитивно. Враховуючи актуальність питання, його широту слід було все ж таки вік, як ознаку не відносити до «інших ознак», а додати в первинний перелік. Вказане принаймні б сприяло актуалізації проблематики на науковому та праксіологічному рівнях.

I наостанок дослідимо принцип справедливості. «Справедливість - поняття про належне, про те, що є надхибним. Вона $є$ метою й сенсом будь-якої соціальної політики та права. Право ж за своєю суттю, природою 
та етимологією передбачається як справедливе. Аналогічно і справедливість існує в межах права та виступає критерієм оцінки соціальних вимог та інтересів як правових чи неправових. Правова справедливість, нарівні зі свободою у юридичному аспекті, $є$ смисловим компонентом категорії рівності у праві як принципу формальної рівності, а не навпаки, і полягає у рівному ставленні до всіх людських істот як до формально рівних» [10, с.65].

Соціальні та фінансові ресурси держави 6 обмеженими та не можуть задовільнити повністю законні інтереси всіх громадян. Тому принцип справедливості актуалізується в сучасних умовах розвитку державності, особливо в контексті вже довготривалих пандемічних загроз. Тому справедливий розподіл державних і громадських ресурсів та механізмів 6 вагомим чинником як запобігання, так і подолання дискримінації за віком.

Висновок. Правова політика демократичної держави повинна забезпечити функціонування органів публічної влади у світлі максимального забезпечення прав та свобод громадян та протидії дискримінації. Принципи правової політики визначають ії основні засади, ключові парадигми.

Автор визначив основні принципи правової політики у досліджуваній сфері. Первинним і основоположним виступає принцип верховенства права. Цей принцип став оновою функціонування конституціоналізму. Верховенство права вказує на необхідності існування системи правових вимог, що полягають у формуванні, зміні, припиненні функціонування правових норм, здійсненні правотворчої діяльності та правореалізаційної практики, існування комплексу нормативно правових актів. Проте тільки вказаним не можна повною мірою задовільнити суспільні інтереси. У зміст принципу законності випливає необхідність функціонування органів державної влади та місцевого самоврядування з неухильним дотриманням визначених правових норм, відповідно до закону та в порядку, передбаченому законом.

На думку автора, принцип рівності також слід визначити як загальний принцип недискримінації. Конституційне закріплення рівності за ознакою віку все ж не може бути оцінено позитивно. Враховуючи актуальність питання, його широту, слід було все ж таки вік, як ознаку, не відносити до «інших ознак», а додати в первинний перелік. Вказане принаймні 6 сприяло актуалізації проблематики на науковому та праксіологічному рівнях.

Також досліджено принцип справедливості, що позиціоновано як справедливий розподіл державних і громадських ресурсів та механізмів, що $є$ вагомим чинником як запобігання, так і подолання дискримінації за віком.

\section{Література}

1. Українці стали більш толерантними й активніше захищають свої права: результати опитування. 10 грудня 2020 p. URL: https://dif.org.ua/article/ukraintsi-stali-bilshtolerantnimi-y-aktivnishe-zakhishchayut-svoiprava-rezultati-opituvannya

2. Народжуваність в Україні знизилася на $40 \%$ за 10 років URL: https:// kontrakty.ua/article/171952 https://kontrakty. ua/article/171952

3. Селіванов В. Правова політика України (деякі теоретичні питання сутності, змісту та технології). Право Украӥни. 2001. № 12. C. $6-14$.

4. Жаровська I. М. Правова політика держави (теоретико-правовий аналіз) $B i$ сник Національного університету "Аввівська політехніка". Серія «Юридичні науки». 2020. T. 7, № 4(28). С. 47-51.

5. Конституція України: закон України від 28.06.1996 № 254к/96-ВР Відомості Верховної Ради Украӥни. 1996. № 30, ст. 141

6. Крикунов О. Конституційний принцип верховенства права та підходи до його інтерпретації у зарубіжних державах та Україні Історико-правовий часопис. 2015. № 1. C. 61-66. C. 65

7. Шевченко $\Lambda$. А. Принцип верховенства права: історія становлення Збірник наукових пращь Харківського начіонального педагогічного університету імені Г. С. Сковороди. «Право». 2020. Вип. 32. С. 7-13

8. Савенко В. В. Законність як шлях матеріалізації ідеалу правової реальності у громадянському суспільстві Актуальні проблеми правознавства. 2020. Вип. 2. С. 12-17. 


\section{АНОТАЦІЯ}

Статтю присвячено аналізу приниипів правової політики у сбері недискримінащї за віковою ознакою. Вказано, що правова політика демократичної держави повинна забезпечити функціонування органів публічної влади у світлі максимального забезпечення прав та свобод громадян та протидї дискримінацій. Принципи правової політики визначають ій основні засади, ключові парадигми.

Автор визначив основні приниипи правовоі політики у досліджуваній сбері. Первинним і основоположним виступає принцип верховенства права. Цей принцип став оновою фбнкиіонування конституиіоналізму. Верховенство права вказує на необхідності існування системи правових вимог, що полягають у бормуванні, зміні, припиненні функиіонування правових норм, здійсненні правотворчої діяльності та правореалізачійної практики, існування комплексу нормативно правових актів. Проте тільки вказаним не можна повною мірою задовільнити суспільні інтереси. Зі змісту принизипу законності випливає необхідність функиіонування органів державної влади та місцевого самоврядування з неухильним дотриманням визначених правових норм, відповідно до закону та в порядку, передбаченому законом.

На думку автора, приници рівності також слід визначити як загальний принцип недискримінації. Конститущійне закріплення рівності за ознакою віку все ж не може бути оиінено позитивно. Враховуючи актуальність питання, його широту, слід було все ж таки вік, як ознаку, не відносити до «інших ознак», а додати в первинний перелік. Вказане принаймні б сприяло актуалізащї проблематики на науковому та праксіологічному рівнях.

Також досліджено принщип справедливості, що позиціоновано як справедливий розподіл державних $і$ громадських ресурсів та механізмів, шо є вагомим чинником як запобігання, так $i$ подолання дискримінацї за віком.

Ключові слова: принципи, правова політи ка, дискримінація, вік, ознаки дискримінаий.

9. Воеводин А. Д. Юридический статус личности в России 1997. 300 с.

10. Васильченко О. П. Рівність як форма вираження буття фізичної особи Форум права. 2014. № 1. С. 59-66.

\section{CONSTITUTIONAL PRINCIPLES OF LEGAL POLICY IN THE FIELD OF AGE NON-DISCRIMINATION}

The article is devoted to the analysis of the principles of legal policy in the field of age nondiscrimination. It is stated that the legal policy of a democratic state should ensure the functioning of public authorities in the light of maximum protection of the rights and freedoms of citizens and anti-discrimination. The principles of legal policy determine its basic principles, key paradigms.

The author identifies the basic principles of legal policy in the study area. The principle of the rule of law is primary and fundamental. This principle became the basis for the functioning of constitutionalism. The rule of law indicates the need for a system of legal requirements, consisting in the formation, change, termination of legal norms, the implementation of law-making activities and law enforcement practices, the existence of a set of regulations. However, these alone cannot fully satisfy the public interest. The content of the principle of legality implies the need for the functioning of state authorities and local self-government in strict compliance with certain legal norms, in accordance with the law and in the manner prescribed by law.

According to the author, the principle of equality should also be defined as a general principle of non-discrimination. The constitutional enshrinement of age equality, however, cannot be assessed positively. Given the urgency of the issue, its breadth should still be age, as a sign not to refer to "other signs", but to add to the original list. This would at least contribute to the actualization of the issue at the scientific and praxiological levels.

The principle of justice, which is positioned as a fair distribution of state and public resources and mechanisms, which is an important factor in both preventing and overcoming age discrimination, is also studied.

Keywords: principles, legal policy, discrimination, age, signs of discrimination. 